\title{
FIELD ACCUMULATION AND TRANSLOCATION OF POTENTIALLY TOXIC ELEMENTS (PTES) FROM INDUSTRIAL SOIL BY THE BIODIESEL PLANT, Jatropha Curcas
}

\author{
* Abdullahi, Z. $^{1}$ and Abdulrahman, A. A. ${ }^{1}$ \\ ${ }^{1}$ Department of Pure and Industrial Chemistry, Bayero University, Kano, Nigeria. \\ *Corresponding Author: azakari.chm@buk.edu.ng
}

\section{ABSTRACT}

Samples of Jatropha curcas,a non-edible biodiesel plant, which tolerates harsh environments was collected from an industrial area with high anthropogenic activities (Challawa Industrial area, Kano, Nigeria)and sorted into leaves, stems and roots. The aim is to assess the potentials of Jatropha curcas in accumulation and translocation of six Potentially Toxic Elements (PTEs) ( $\mathrm{Zn}, \mathrm{Cu}, \mathrm{Cd}, \mathrm{Cr}$, Pb and Ni) from the soil media. Atomic Absorption Spectroscopy (AAS) was used to assess the concentrations. The bioaccumulation/ transfer of metals from roots to shoots and from soil to roots were evaluated in terms of translocation (TF) and bioconcentration factor (BCF). TF values of 1.02, 4.92, 2.68, 3.73, 1.5 and 3.19 for $\mathrm{Zn}, \mathrm{Cu}, \mathrm{Cd}, \mathrm{Cr}, \mathrm{Pb}$ and Ni respectively indicate that $J$. curcas was efficient in translocation of PTEs from roots to shoots. This is an indication that the plant is therefore suitable for phytoextraction of $\mathrm{Zn}, \mathrm{Cu}, \mathrm{Cd}, \mathrm{Cr}, \mathrm{Pb}$ and $\mathrm{Ni}$. But $B C F$ value of 0.66 and 0.70 for $\mathrm{Cu}$ and $\mathrm{Pb}$ on the other hand shows that J. curcas is less able to translocate these two metals ( $\mathrm{Cu}$ and $\mathrm{Pb}$ ) indicating ineffective transfer. This show that J. curcasmay be suitable a candidate for phytostabilization of Copper and lead in contaminated soils in the study area.

Key words: PTEs, Jatropha curcas, translocation, phytoextraction, bioaccumulation and phytostabilization

\section{INTRODUCTION}

Potentially toxic elements (PTEs) pollution has become a major environmental issue worldwide (Xiaogang Li et al., 2020; Si et al., 2021). As a result, soil, an important sink of nutrients and pollutants, plays a vital role in environmental sustainability and security(Wu et al., 2018). Unfortunately, soil pollution has turned out to be a drawback in terms of human advancement and general health wellbeing recently(Jiang et al., 2017; Padoan et al., 2017). Soil contaminated with PTEs is of great environmental concern since these contaminants are taken up by living organisms, added as run-offs to water bodies and transported to other remote areas Ghosh \& Maiti, (2020). Heavy metals, which are among the Potentially Toxic Elements (PTEs), are defined as metallic constituents with atomic number $>20$ and density $>6 \mathrm{~g} \mathrm{~cm}^{3}$ (Zulfiqar et al., 2019). They have attracted attention in recently due to the fact that these heavy metals are generally refractory and cannot be degraded (Xingyuan Li et al., 2021). Over the years vast number of research has been carried out to solve this challenging scenario. Physical, chemical and biological methods have been advocated to remediate metal contaminated soils (Sivakumar et al., 2020). Most of these techniques are conventional remediation technologies which has to do with physical, and chemical methods in order to bring contamination to adequate level (Guo et al., 2020). However, phytoremediation has been recognized as cost effective method for remediation of metal contaminated soils (Chauhan et al., 2020). Phytoremediation in simple terms refers to the use of plants and associated soil microbes to reduce the concentrations or toxic effects of contaminants in the environment (Álvarez-mateos \& Garcíamartín 2019). There are two major approach to phytoremediation. One of such approach is phytoextractionuses plants ability to assimilate toxic metals from belowground parts and transfer them to other tissues of plants where they may accumulate. Phytoextraction is a solar-driven technique which uses plant roots to translocate heavy metals from soil to other tissues of plants located above the ground (Xiong Li \& Yang, 2020). As for phytostabilization, it's a technology which utilizes the ability of plants to reduce the bioavailability and mobility of toxic metals and stabilize them below the ground in soils(Xiong Li \& Yang 2020). Despite the fact that traditional phytoremediation by using green plants to 
BAJOPAS Volume 14 Number 1, June, 2021 alleviate soil contamination seems a viable approach to tackle the Problem of Potentially toxic elements, it has not been applied successfully as a result of a number of limitations. Some of these limitations are slow growth and low biomass of plants and low bioavailability of heavy metals in soil(Álvarezmateos \& García-martín, 2019). Others are, the fact that it takes time to clean up the contaminated soil and very small concentrations of metals is bioavailable which varies with some soil properties like $\mathrm{pH}$ and organic matter. $J$. curcas (Family: Euphorbiacae) a non-edible, potential biodiesel plant, which can survive harsh environments of semi-arid agro-climatic conditions and wastelands (Moursy et al., 2014)was selected for this study. Literature is abound on research using this plant as an accumulator of metals however report on its accumulation ability in proportion to background metal concentration in this industrial area is limited. The aim of the study is to assess the potentials of $J$. curcas in the accumulation and translocation of six heavy metals in tissues of this plant growing naturally at Challawa Industrial Estate and its suitability in phytoremediation. A Picture of J. curcasis shown in plate 1.

\section{MATERIALS AND METHODS \\ Preparation of Reagents}

In the preparation of reagents, chemicals of analytical grade purity and deionized water were used throughout the analysis. All the laboratory apparatus (glass wares and the plastic containers) were first soaked in nitric-acid and thoroughly washed with detergent solution, followed by several rinses with tap water, deionized water and finally with the analyte samples.

\section{Study Area}

The field study was carried out in the vicinity of Challawa Industrial area. The area is located in Kumbotso local government of Kano state. Sampling was done at Yandanko village in Challawa Industrial area, located between latitudes $11^{\circ} 52^{\prime} 48.81^{\prime \prime}$ and along longitudes $8^{\circ} 28^{\prime} 17.25^{\prime \prime}$. The Global Positioning System (GPS) was used in recording the coordinates and Geographical Information System (GIS) was used to locate the map of the study area as shown below (Figure 1).

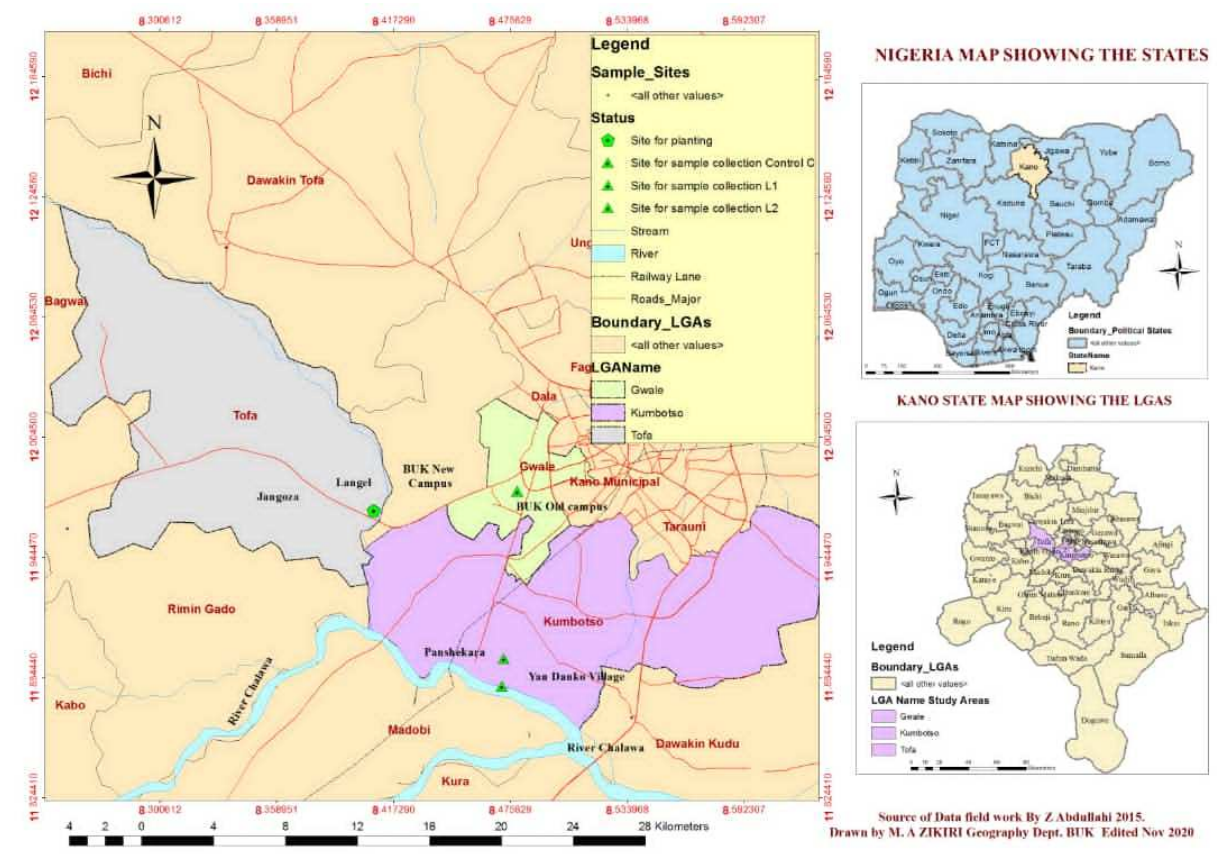

Figure 1: Map of Kumbotso and Tofa LGA Showing Sampling location

Field Sampling of Soil and Plant Species (Yan danko Challawa and Langel Village, Tofa LGA).

Nine sampling points from three locations were systematically established after every $100 \mathrm{~m}$. Jatropha curcas was collected for analysis with Identification of the collected plant specie was done at the Plant Biology Department of Bayero at least three species per sampling point including the control site (Langel village), which was far away from Challawa Industrial area. The plant specie was collected from this sites at almost similar stage of growth as that from the Challawa sample and were used as the control. University Kano and a herbarium numberJatropha curcas (bukhan 0060) was 
BAJOPAS Volume 14 Number 1, June, 2021 assigned to the plant. The sample was labeled, placed in polythene bags and transported to the University and air-dried. Three soil samples were also collected at each sampling point for the plant and composites obtained. The composite soil samples was air dried and ground into fine powder using pestle and mortar and sieved through $2 \mathrm{~mm}$ plastic mesh and stored in labeled polythene bags.

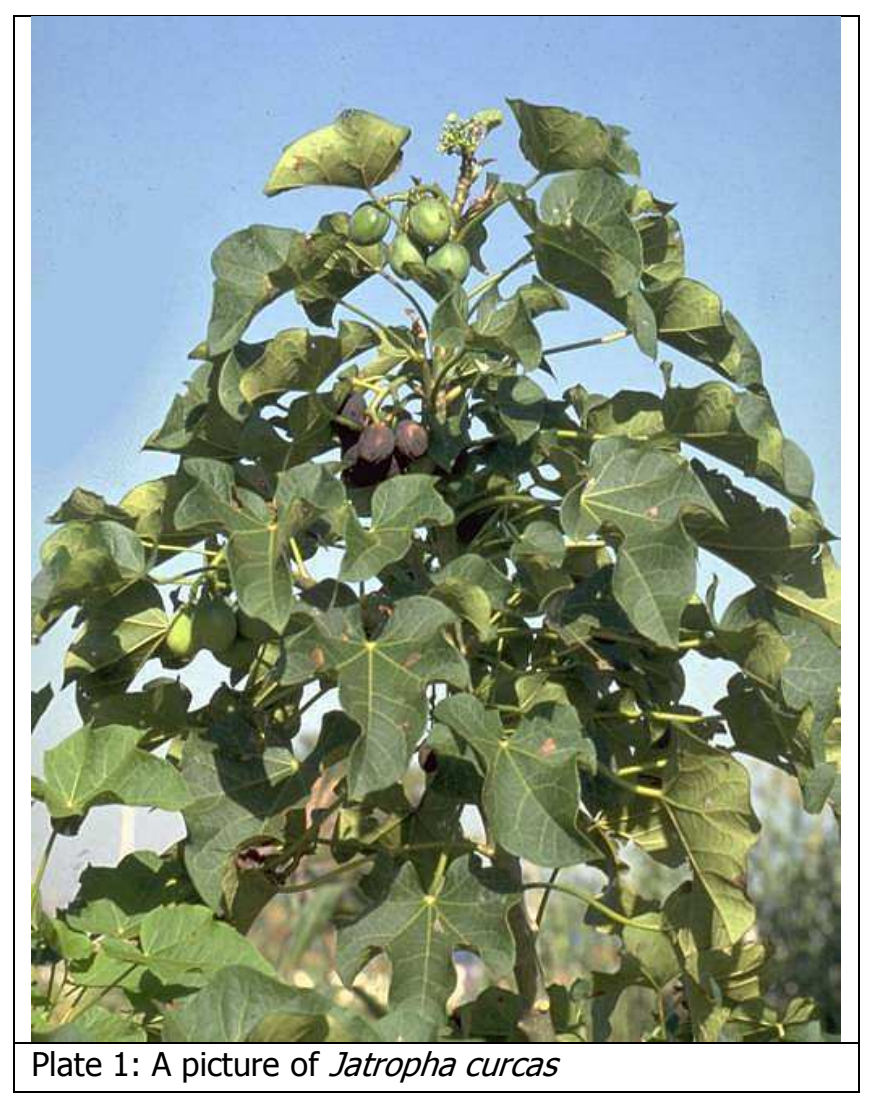

\section{Digestion of Soil Samples}

$1 \mathrm{~g}$ of the soil sample from Yandanko, at Challawa was mixed with $20 \mathrm{~cm}^{3}$ of nitric acid $\left(\mathrm{HNO}_{3}\right)\left(70 \% \mathrm{w} / \mathrm{v}, \mathrm{S} . \mathrm{G} 1.42 \mathrm{~g} / \mathrm{cm}^{3}\right)$ and allowed to stand for 1 hour. $15 \mathrm{~cm}^{3}$ of perchloric acid $\left(\mathrm{HClO}_{4}\right)\left(70 \%\right.$ w/v, S.G $\left.1.67 \mathrm{~g} / \mathrm{cm}^{3}\right)$ was then added and the mixture was placed in a sand bath and heated at $55^{\circ} \mathrm{C}$ until dense white fumes were observed. It was allowed to cool and filtered into the $100 \mathrm{~cm}^{3}$ volumetric flask and made to the mark. The resulting solution was analyzed for metal concentrations using Atomic Absorption Spectrophotometer Buck scientific, Model-210VGP (Tanee aand Amadi, 2016).

\section{Plant Tissue Analysis}

Before the analyses root and shoot samples were thoroughly washed using distilled water to remove all adhering soil particles. Samples were then oven dried to constant weights at $105^{\circ} \mathrm{C}$. Each dried sample was ground to powder and 0.5 gram of each sample was used for analysis. These samples were placed in a crucible and transferred to the muffle furnace and ashed at $550^{\circ} \mathrm{C}$. The ash is then dissolved in $10 \mathrm{ml} 0.1 \mathrm{M}$ nitric acid, filtered and made up to the $100 \mathrm{~cm}^{3}$ mark and analyzed for metal content using Atomic Absorption spectrophotometer (Inuwa and Mohammed, 2018).

\section{Statistical analysis}

All data gathered were analyzed statistically using analysis of variance (ANOVA). When significant differences were detected between treatments, Tukey test (at $P<0.05$ ) was calculated for each parameter and all graphs were plotted by employing Microsoft Excel.

\section{RESULTS AND DISCUSSION}

The soil physico-chemical characteristics from the study area have been reported in our earlier works. Results revealed that the area is characterized by sandy texture (66.8\%).As indicated from earlier report, the $\mathrm{pH}$ of soil was slightly acidicwith a value of 6.0 while that of the control is 6.8 (Zakari and Audu, 2021). 
BAJOPAS Volume 14 Number 1, June, 2021 Potentially Toxic Elements (PTEs) in $J$. curcas

The data obtained from the field studies show that the PTEs contents in the plant tissues varied among plant species, which reflected the edaphic metal conditions in the area under study. Fig 2-7 is a chart representing the levels of all six studied PTEs $(\mathrm{Zn}, \mathrm{Cu}, \mathrm{Cd}, \mathrm{Cr}, \mathrm{Pb}$, and $\mathrm{Ni}$ ) in tissues (leaf, stem, roots) and rhizospheric soil samples in $J$. curcas sampled from Challawa Industrial Area. In Fig 2, the observed $\mathrm{Zn}$ concentrations $\left(\mathrm{mg} \mathrm{kg}^{-1}\right)$ in $J$. curcas are; $55.16 \pm$ $15.49,84.09 \pm 24.09,136.16 \pm 38.34$, and $93.16 \pm$ 24.08 in leaf, stem, root and rhizospheric soil samples respectively. The $\mathrm{Zn}$ concentration in the tissues follows the decreasing order as root > stem > leaf. One way Anova shows that there is significant difference between the $\mathrm{Zn}$ levels in the leaf, stem, root

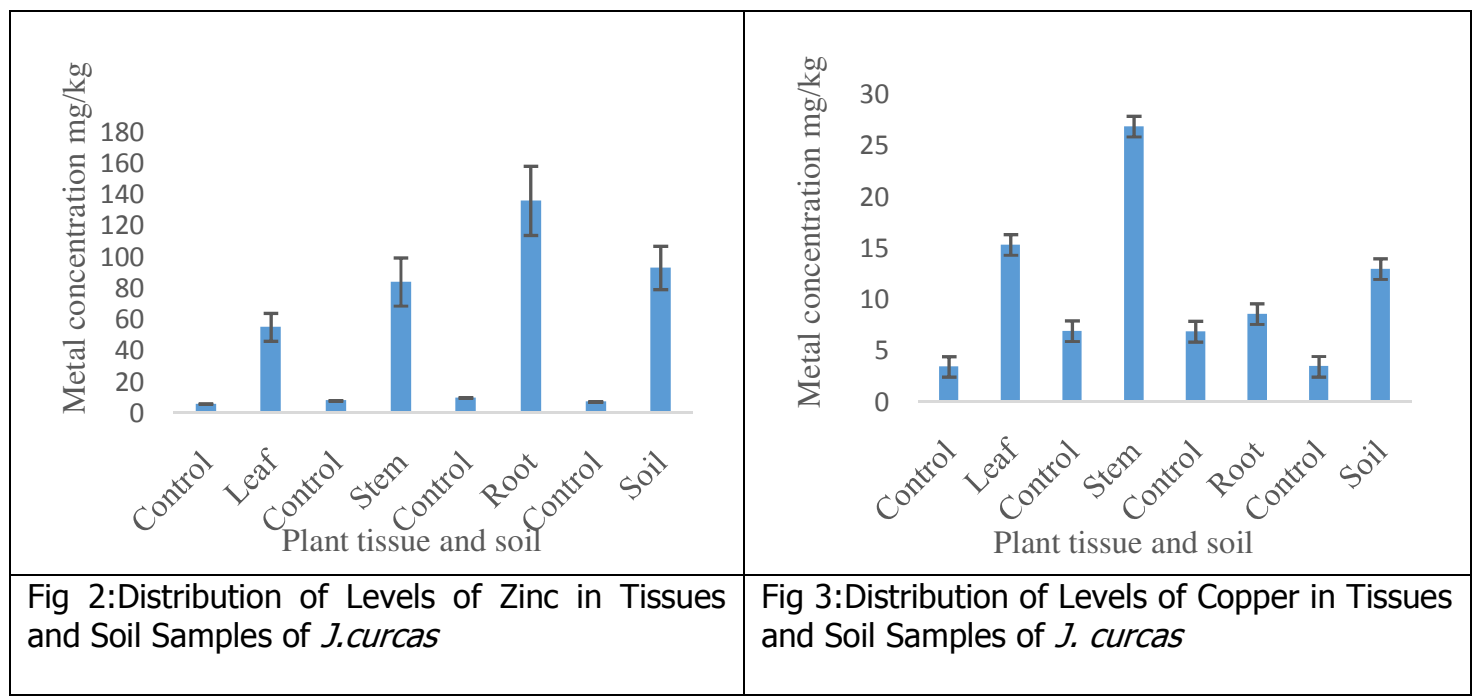

The Cu concentration in the J. curcas tissues follows the decreasing order pattern as stem > leaf $>$ root. One way Anova shows that there is significant difference between the Cu levels in the leaf, stem, root and soil at $P<0.05$. The Tukey test however, revealed that there is no significant difference at $P<0.05$ between the levels of $\mathrm{Cu}$ in soil, leaf and root. However, the $\mathrm{Cu}$ levels in the stem is significantly higher than those obtained in the root and leaf. However, results showed that stem tissues were found to accumulate a very high amounts of $\mathrm{Cu}$ than the roots and leaf as depicted by fig 3. Our results agree with the findings of Abdullahi et al, 2016, Wu et al., 2011 for the same plant. Cu is an essential micronutrient in trace quantities, but it can be a potential toxicant at high concentrations(Hou et al., 2018).It can also lead to morphological, anatomical and physiological changes in plants (Hou et al., 2018).

The $\mathrm{Cd}$ concentration in the $J$. curcas tissues follows the decreasing order pattern as leaf > stem > root. One way Anova shows that there is significant difference between the $\mathrm{Cd}$ levels in the leaf, stem, root and soil at $\mathrm{P}<0.05$. The Turkey test however, revealed that the $\mathrm{Zn}$ levels in the root is significantly higher than those obtained in the stem, soil and leaf. However, there is no significant difference at $P<0.05$ between the levels of zinc in the leaf and stem. This observation was also noticed for the soil and the stem which shows no significant difference. However, the results showed that roots were found to accumulate considerable amounts of $\mathrm{Zn}$ than leaf and stem tissues compared to their levels in similar tissues of the control as depicted by fig 2 . This results agrees with the findings of Abdullahi et al, 2016,Waziri et al., 2016, Wu et al., 2011and Ahmadpour et al., 2010, for the same plant. Zinc is an essential trace element required for plant growth and it is very important in many metabolic processes in plants(Ji et al., 2021). and soil at $P<0.05$. The Tukey test however, revealed that the $\mathrm{Cd}$ levels in the leaf is significantly higher than those obtained in the stem and root. However, there is no significant difference between the levels of $\mathrm{Cd}$ in root and stem. Additionally, the Cd levels in the rhizospheric soil is significantly lower than that of the levels in the leaf, root and stem. Among the heavy metals, $\mathrm{Cd}$ is relatively mobile in the soil and can be toxic to both plants and animals (Rizwan et al., 2017). Results obtained showed that accumulation of $\mathrm{Cd}$ in $\mathrm{J}$. curcas is found to be higher in leaf than both the stem and root tissues compared to their levels in similar tissues of the control as depicted by fig 4.This results agrees with the findings of Chang et al., (2014), Abdullahi et al, (2016) and Waziri et al., (2016) for the same plant. Uptake of $\mathrm{Cd}$ in plants is controlled by its concentration and bioavailability in soil which are influenced by soil properties(Wang et al., 2021).Cd is one of the most phytotoxic elements and does not have a known biological function in plants (Dobrikova et al., 2021). 


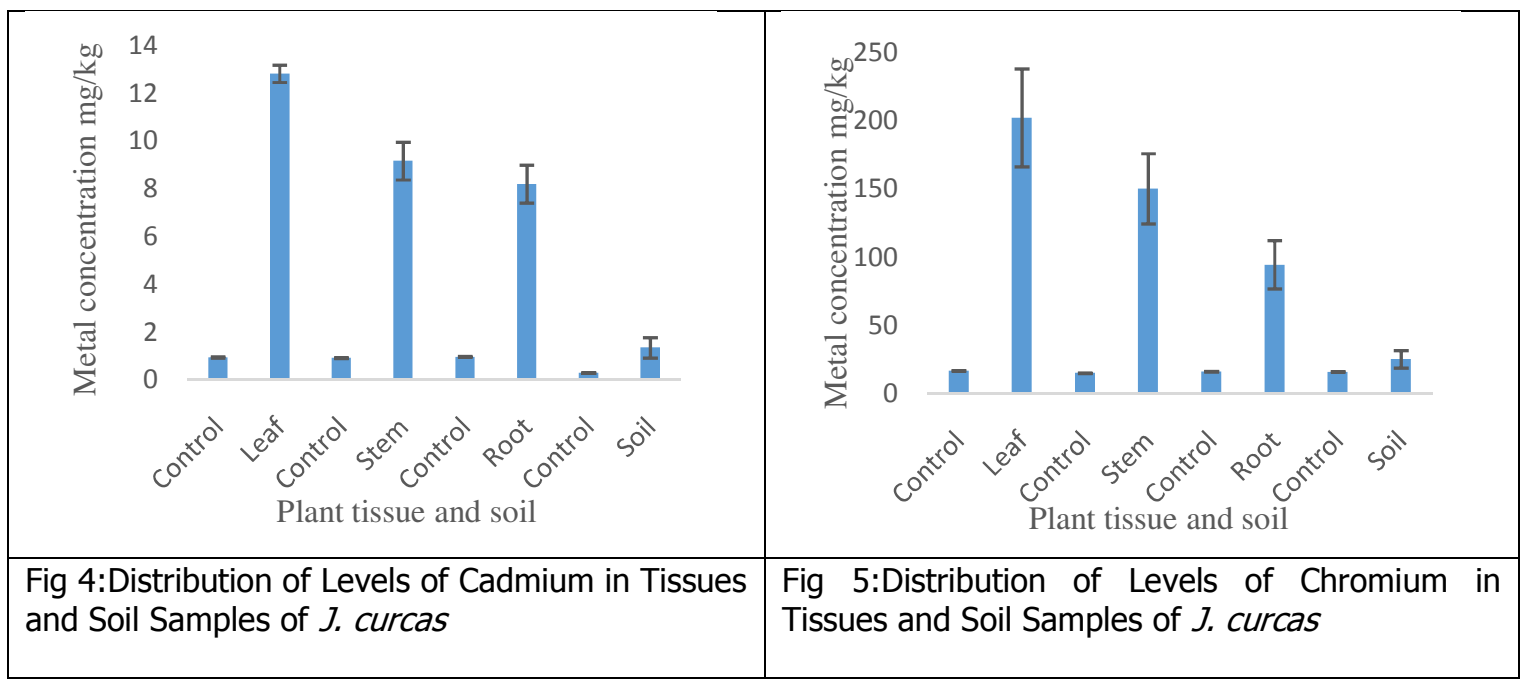

The $\mathrm{Cr}$ concentration in the $\mathrm{J}$. curcas tissues follows the decreasing order pattern as leaf $>$ stem $>$ root. One way Anova shows that there is significant difference between the $\mathrm{Cr}$ levels in the leaf, stem, root and soil at $P<0.05$. The Tukey test however, revealed that the $\mathrm{Cr}$ levels in the soil is significantly lower than those obtained in the tissues (root, stem and leaf). However, there is no significant difference between the levels of $\mathrm{Cr}$ in the root and the stem. It also shows that, there is no significant difference between $\mathrm{Cr}$ levels in the stem and leaf. However, results showed that roots were found to accumulate considerable amounts of $\mathrm{Cr}$ than leaf and stem as depicted by fig 5 . Our results agree with the findings of Chang et al., (2014)Abdullahi et al, (2016), Waziri et al., (2016) and Wu et al., (2011) for the same plant. In nature, $\mathrm{Cr}$ exists in two different stable oxidation states i.e., trivalent $\mathrm{Cr}^{3+}$ and hexavalent $\mathrm{Cr}^{6+}$ forms. $\mathrm{Cr}^{3+}$ and $\mathrm{Cr}^{6+}$ differ in terms of mobility, bioavailability and toxicity. $\mathrm{Cr}^{6+}$ has been found to be more toxic than $\mathrm{C}^{\mathrm{r} 3+}$ (Patra et al., 2018).

The $\mathrm{Pb}$ concentration in the $\mathrm{J}$. curcas tissues follows the decreasing order pattern as root $>$ stem $>$ leaf. One way Anova shows that there is significant difference between the $\mathrm{Pb}$ levels in the leaf, stem, root and soil at $P<0.05$. The Tukey test however, revealed that the $\mathrm{Pb}$ levels in the soil is significantly higher at $\mathrm{P}$ $<0.05$ than those obtained in the root, stem and leaf. However, there is no significant difference between the levels of $\mathrm{Pb}$ in the leaf and stem on the one hand and stem and root on the other hand. In addition, the $\mathrm{Pb}$ levels in the leaf is significantly lower than that of the root. However, results showed that roots and stem were found to accumulate large amounts of $\mathrm{Pb}$ than the leaf as depicted by figs 6.This results is consistent with the findings of Chang et al., (2014). $\mathrm{Pb}$ is known for its negative effect on chlorophyll biosynthesis and nutrient metabolism in several species El et al., (2020).

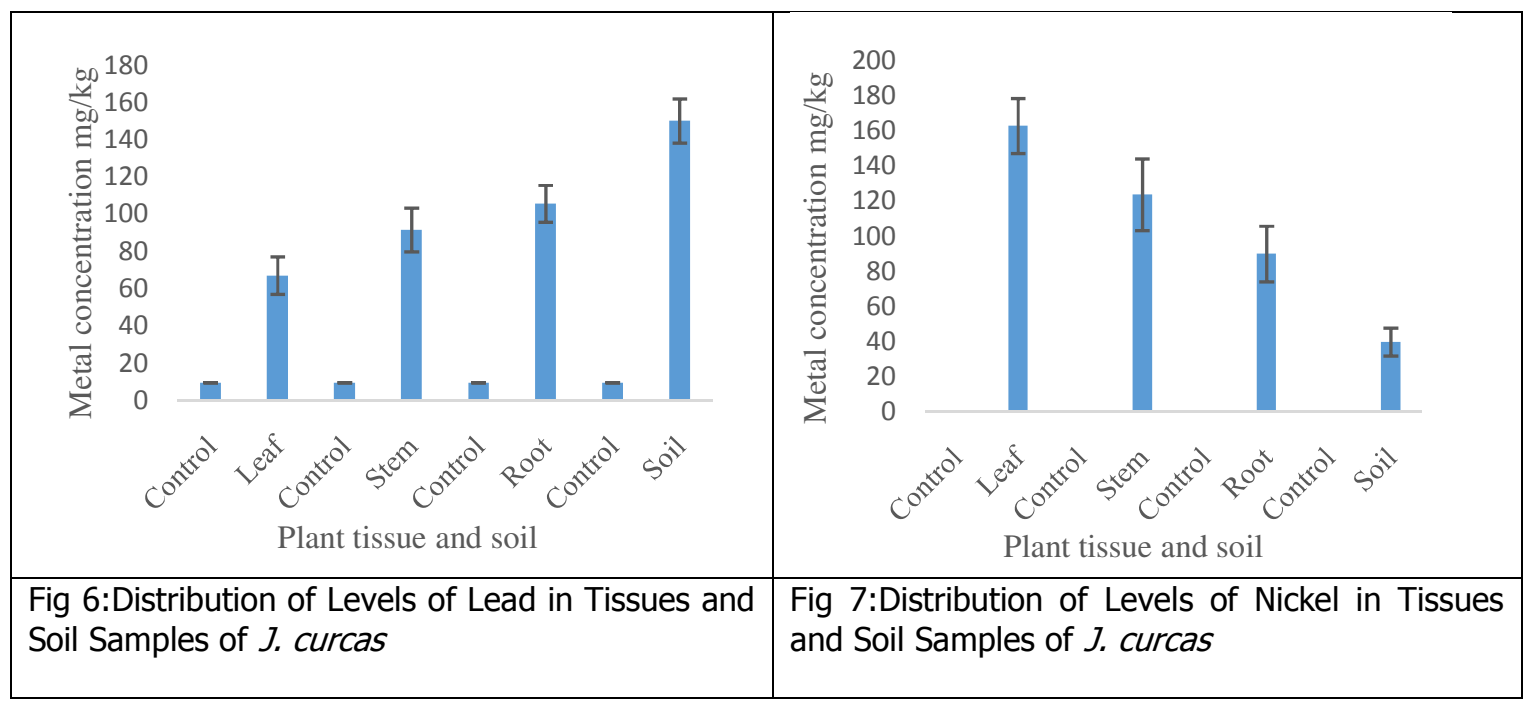


BAJOPAS Volume 14 Number 1, June, 2021

Nickel is an essential nutrient for plants, but a high concentrations of $\mathrm{Ni}$ metal, adversely affects plant growth and both quality and yield of plants Heidari et al., (2020). For Ni levels, a decreasing order pattern, leaf $>$ stem >root was observed in the tissues of J. curcas. One way Anova shows that there is significant difference between the $\mathrm{Ni}$ levels in the leaf, stem, root and soil at $\mathrm{P}<0.05$.The Tukey test revealed that the $\mathrm{Ni}$ levels in the leaf is significantly higher than those obtained in the stem, root and soil. However, there is no significant difference between the levels of $\mathrm{Ni}$ in root and stem. Also, the Ni levels in the soil is significantly lower than that of the leaf, stem and root. However, results showed that roots were found to accumulate considerable amounts of $\mathrm{Ni}$ than leaf and stem as depicted by figs 7 . Our results agree with the findings of Abdullahi et al, (2016) and Wu et al., (2011) for the same plant.

\section{Bioaccumulation and Translocation in Field Plants}

The Bioconcentration factor (BCF) was determined by as previously described in-situ Phytoextraction potential in native hyperaccumulator plants Sharma et al., (2020). While the translocation factor (TF) was evaluated by calculating the ratio of metal concentration in plant shoot and metal concentration in plant root (Sharma et al., 2020;Amir et al., 2020). The Translocation and Bioaccumulation in $J$. curcas is as shown in Figs 8 and 9 respectively.

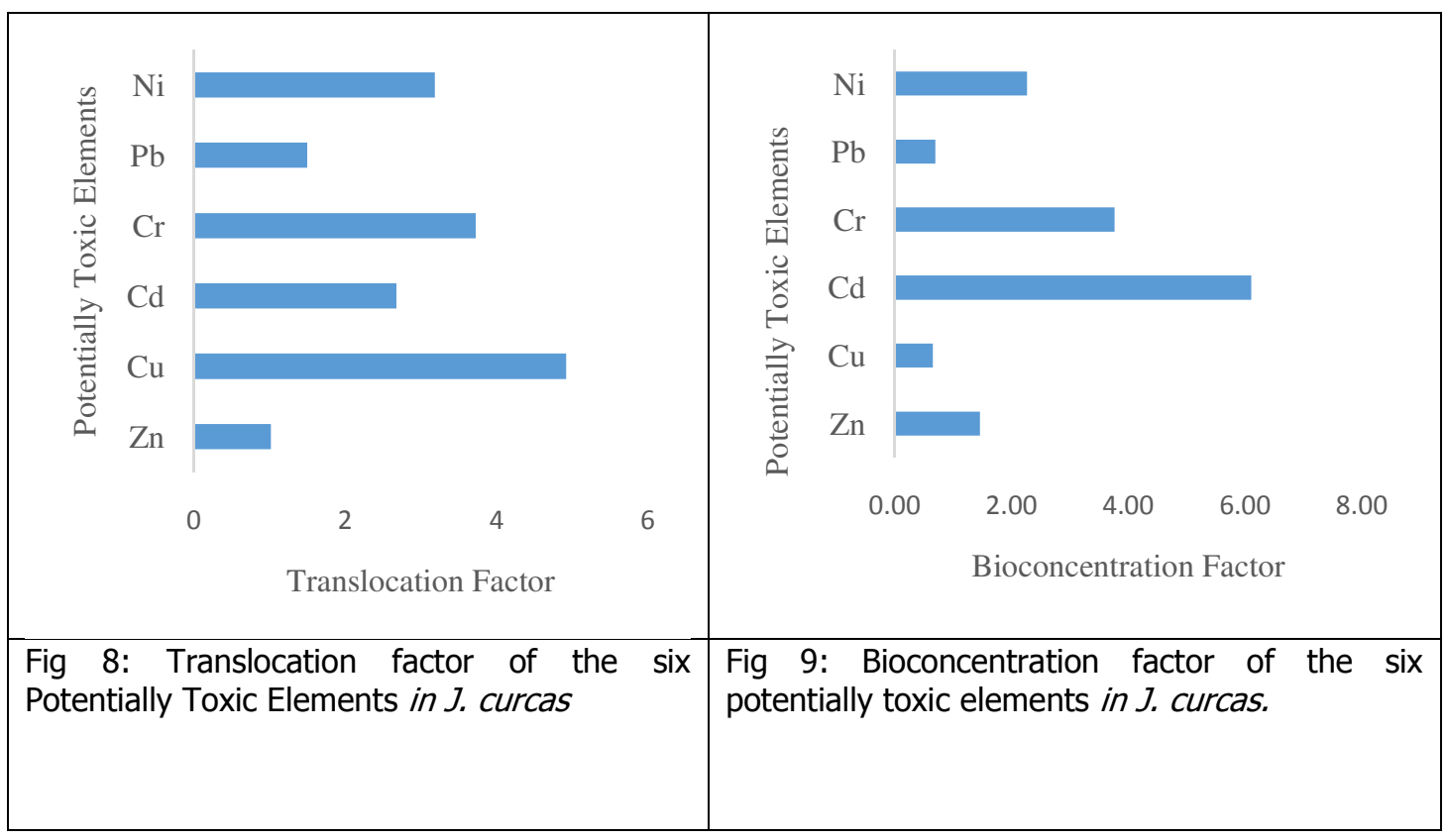

The Translocation and Bioaccumulation in $J$. curcas is as shown in Figs 8 and 9 respectively. The translocation factors (TF) expresses the ability of a plant to translocate heavy metals from the root to shoot in the soil-plant system (Álvarez-mateos \& García-martín, 2019). TF determines plant efficiency in heavy metals translocation from the roots to the shoots. It shows whether the native plant can be classified as an accumulator, excluder or indicator. A plant is considered efficient in metal translocation from root to shoot when TF $>1$; the reason being an efficient metal transport system TF < 1 , suggest an ineffective metal transfer indicating that such plant species accumulate metals mostly or substantially in the roots and rhizomes than in the shoot portions or the leaves of plants (Usman et al., 2019). Bioconcentration factor (BCF) on the other hand, can be used to evaluate a plant's phytoremediation potential. A BCF value $>1$ indicate that a plant is a hyperaccumulator whereas, a value less than one is indicative of an excluder(Usman et al., 2019) .Both BCF and TF have to be considered for evaluating whether a plant is a metal hyperaccumulator. A hyperaccumulator plant should have $B C F>1$ or TF > 1(Sharma et al., 2020). J. curcas was screened for $\mathrm{Zn}, \mathrm{Cu}, \mathrm{Cd}, \mathrm{Cr}, \mathrm{Pb}$, and $\mathrm{Ni}$. Results show that it has the ability to take up and translocate more than one heavy metal from roots to shoots as shown in figs $8 \mathrm{a}$ and $8 \mathrm{~b}$ with noticeable variations between TF and BCF. 
BAJOPAS Volume 14 Number 1, June, 2021

Fig 8depicts that $J$. curcas was able to translocate PTEs from roots to shoots with TF values of 1.02, 4.92, 2.68,3.73, 1.5 and 3.19 for $\mathrm{Zn}, \mathrm{Cu}, \mathrm{Cd}, \mathrm{Cr}, \mathrm{Pb}$ and Nirespectively. This shows that this plant may be considered for phytoextraction of these elements. In Fig 9, which shows the BCF values for J. curcas, BCF > 1 were observed for the elements $\mathrm{Zn}(1.46), \mathrm{Cd}$ (6.11), $\mathrm{Cr}$ (3.77), and $\mathrm{Ni}(2.27)$ with the exception of $\mathrm{Cu}(0.66)$ andPb (0.70)which had a BCF < 1.Therefore, $\mathrm{Zn}, \mathrm{Cd}$, Crand Ni with both TF and BCF values greater than 1 shows that $J$. curcas is able to efficiently translocate all these 4 elements. But BCF value of 0.66 and 0.70 for $\mathrm{Cu}$ and $\mathrm{Pb}$ on the other hand shows that $J$. curcas is less able to translocate these two metals (Cu and $\mathrm{Pb}$ ) indicating ineffective transfer.

\section{CONCLUSION}

The potential for phytoremediation through bioaccumulation of $J$. curcas against six PTEs $(\mathrm{Zn}, \mathrm{Cr}, \mathrm{Cd}, \mathrm{Cu}, \mathrm{Ni}$ and $\mathrm{Pb}$ ) was studied. In the course of this study, we can reasonably conclude

\section{REFERENCES}

Abdullahi, U. (2016). Phytoremediation of Contaminated Soils from Challawa Industrial Estate, Kano-Nigeria. Science Journal of Analytical Chemistry, 4(5), 59. https://doi.org/10.11648/j.sjac.2016040 5.11

Ahmadpour, P., Nawi, A. M., Abdu, A., Abdulhamid, H., Singh, D. K., Hassan, A., Majid, N. M., Jusop, S., \& Serdang, U. P. M. (2010). Uptake of Heavy Metals by Jatropha curcas L. Planted in Soils Containing Sewage Sludge Department of Forest Management, Faculty of Forestry, Laboratory of Sustainable Bioresource Management, Institute of Tropical Forestry and Forest Products, Departm. 710$),$ 1291-1298.

Álvarez-mateos, P., \& García-martín, J. F. (2019). Phytoremediation of highly contaminated mining soils by Jatropha curcas $L$. and production of catalytic carbons from the generated biomass. Journal of Environmental Management, 231(April 2018), 886-895. https://doi.org/10.1016/j.jenvman.2018. 10.052

Amir, W., Farid, M., Farid, S., Zubair, M., Alharby, H. F., Bamagoos, A. A., Rizwan, M., Raza, N., Rehman, K., \& Ali, S. (2020). Chemosphere Accumulation potential and tolerance response of Typha latifolia L . under citric acid assisted phytoextraction of lead and mercury.

257. that the plantis a resistant species containing in its tissues amounts of PTEs that were much higher than those considered toxic for normal plants.Based on the translocation factor (TF) and the bio concentration factor (BCF) values, the study show the suitability of this plant for both phytoextraction of $\mathrm{Zn}, \mathrm{Cu}, \mathrm{Cr}$ and $\mathrm{Ni}$ and phytostabilization of $\mathrm{Cd}$ and $\mathrm{Pb}$ in the study area and where desired.

Disclosure statement: Conflict of Interest: The authors declare that there are no conflicts of interest.

Compliance with Ethical Standards: This article does not contain any studies involving human or animal subjects.

Author's contributions: Zakari Abdullahi conducted the research while Prof A.A Audu supervised the research.

Acknowledgement: The authors wish to acknowledge the financial support from Bayero University, Kano, Nigeria through the Directorate of research, innovation and partnerships research grant (BUK/DRIP/RG/2017/0063).

https://doi.org/10.1016/j.chemosphere. 2020.127247

Chang, F. C., Ko, C. H., Tsai, M. J., Wang, Y. N., \& Chung, C. Y. (2014). Phytoremediation of heavy metal contaminated soil by Jatropha curcas. Ecotoxicology, 23(10), 1969-1978. https://doi.org/10.1007/s10646-0141343-2

Chauhan, P., Rajguru, A. B., Dudhe, M. Y., \& Mathur, J. (2020). Environmental Technology \& Innovation Efficacy of lead ( $\mathrm{Pb}$ ) phytoextraction of five varieties of Helianthus annuus $L$. from contaminated soil. Environmental Technology \& Innovation, 18, 100718. https://doi.org/10.1016/j.eti.2020.10071 8

Dobrikova, A. G., Apostolova, E. L., Han, A., Yotsova, E., Borisova, P., Sperdouli, I., Adamakis, I. S., \& Moustakas, M. (2021). Ecotoxicology and Environmental Safety Cadmium toxicity in Salvia sclarea L .: An integrative response of element uptake, oxidative stress markers, leaf structure and photosynthesis. 209. https://doi.org/10.1016/j.ecoenv.2020.1 11851

El, I., Fahr, M., Abourouh, M., Bendaou, M., Zine, T., Abidine, E., Abdelkarim, G., Didier, B., Laurent, L., \& Abdelaziz, S. (2020). Zinc, lead, and cadmium tolerance and accumulation in Cistus libanotis, Cistus albidus, and Cistus 
BAJOPAS Volume 14 Number 1, June, 2021 salviffolius: Perspectives on phytoremediation. 73-80. https://doi.org/10.1002/rem.21638

Ghosh, D., \& Maiti, S. K. (2020). Biochar assisted phytoremediation and biomass disposal in heavy metal contaminated mine soils: a review. International Journal of Phytoremediation, o(0), 1-18. https://doi.org/10.1080/15226514.2020. 1840510

Godwin, E., \& Oluwagbemiga, D. (2020). Search for autochthonous plants as accumulators and translocators in a toxic metal-polluted coal mine soil in. Scientific African, 10, e00630. https://doi.org/10.1016/j.sciaf.2020.e00 630

Guo, H., Jiang, J., Gao, J., Zhang, J., Zeng, L., Cai, M., \& Zhang, J. (2020). Evaluation of cadmium hyperaccumulation and tolerance potential of Myriophyllum aquaticum. Ecotoxicology and Environmental Safety, 195(October 2019), 110502. https://doi.org/10.1016/j.ecoenv.2020.1 10502

Harcourt, P. (2016). JOURNAL OF APPLIED $S$ CIENCE AND E NVIRONMENTAL Screening of Polyalthia longifolia and Aloe vera for their phytoextractability of heavy metals in tropical soil of the Niger Delta.

Heidari, J., Amooaghaie, R., \& Kiani, S. (2020). Impact of chitosan on nickel bioavailability in soil, the accumulation and tolerance of nickel in Calendula tripterocarpa. International Journal of Phytoremediation, $O(0), \quad 1-10$. https://doi.org/10.1080/15226514.2020. 1748564

Hou, S., Zheng, N., Tang, L., \& Ji, X. (2018). Ecotoxicology and Environmental Safety $E$ ff ects of cadmium and copper mixtures to carrot and pakchoi under greenhouse cultivation condition. Ecotoxicology and Environmental Safety, 159(April), 172-181. https://doi.org/10.1016/j.ecoenv.2018.0 4.060

Ji, C., Li, J., Jiang, C., Zhang, L., Shi, L., Xu, F., \& Cai, H. (2021). Zinc and nitrogen synergistic act on root-to-shoot translocation and preferential distribution in rice. Journal of Advanced Research, XXXX. https://doi.org/10.1016/j.jare.2021.04.0 05

Jiang, Y., Chao, S., Liu, J., Yang, Y., \& Chen, Y. (2017). Chemosphere Source apportionment and health risk assessment of heavy metals in soil for a township in Jiangsu Province, China. Chemosphere, 168, 1658-1668. https://doi.org/10.1016/j.chemosphere. 2016.11.088

Li, Xiaogang, Xiao, J., Salam, M. M. A., Ma, C., \& Chen, G. (2020). Impacts of bamboo biochar on the phytoremediation potential of Salix psammophila grown in multi-metals contaminated soil. International Journal of Phytoremediation, $\quad \alpha(0), \quad 1-13$. https://doi.org/10.1080/15226514.2020. 1816893

Li, Xingyuan, Geng, T., Shen, W., Zhang, J., \& Zhou, Y. (2021). Ecotoxicology and Environmental Safety Quantifying the influencing factors and multi-factor interactions affecting cadmium accumulation in limestone-derived agricultural soil using random forest ( $\mathrm{RF}$ ) approach. Ecotoxicology and Environmental Safety, 209, 111773. https://doi.org/10.1016/j.ecoenv.2020.1 11773

Li, Xiong, \& Yang, Y. (2020). Plant Diversity Preliminary study on $\mathrm{Cd}$ accumulation characteristics in Sansevieria trifasciata Prain. Plant Diversity, 42(5), 351-355. https://doi.org/10.1016/j.pld.2020.05.00 1

Mohammed, M. I., \& Inuwa, Y. (2018). Assessment of metals pollution in some herbs from Kano metropolis. Bayero Journal of Pure and Applied Sciences, 10(1), 356. https://doi.org/10.4314/bajopas.v10i1.7 $1 \mathrm{s.}$

Moursy, A. A., Aziz, H. A. A., \& Mostafa, A. Z. (2014). The effect of irradiated and non irradiated sewage sludge application on Uptake of Heavy Metals by Jatropha curcas L plants. 2(1), 1072-1080.

Padoan, E., Romè, C., \& Ajmone-Marsan, F. (2017). Bioaccessibility and size distribution of metals in road dust and roadside soils along a peri-urban transect. Science of the Total Environment, 601-602, 89-98. https://doi.org/10.1016/j.scitotenv.2017 .05 .180

Patra, D. K., Pradhan, C., \& Patra, H. K. (2018). An in situ study of growth of Lemongrass Cymbopogon flexuosus (Nees ex Steud.) W. Watson on varying concentration of Chromium $(\mathrm{Cr}+6)$ on soil and its bioaccumulation: Perspectives on phytoremediation 
BAJOPAS Volume 14 Number 1, June, 2021 potential and phytostabilisation of chromium toxicity. Chemosphere, 193, 793-799.

https://doi.org/10.1016/j.chemosphere. 2017.11.062

Rizwan, M., Ali, S., Adrees, M., Ibrahim, M., Tsang, D. C. W., Zia-ur-Rehman, M., Zahir, Z. A., Rinklebe, J., Tack, F. M. G., \& Ok, Y. S. (2017). A critical review on effects, tolerance mechanisms and management of cadmium in vegetables. Chemosphere, 182, 90-105. https://doi.org/10.1016/j.chemosphere. 2017.05.013

Sharma, P., Tripathi, S., \& Chandra, R. (2020). Heliyon Phytoremediation potential of heavy metal accumulator plants for waste management in the pulp and paper industry. Heliyon, 6(July), e04559. https://doi.org/10.1016/j.heliyon.2020.e 04559

Si, L., Zhang, J., Hussain, A., Qiao, Y., \& Zhou, J. (2021). Ecotoxicology and Environmental Safety Accumulation and translocation of food chain in soilmulberry ( Morus alba L . ) -silkworm ( Bombyx mori ) under single and combined stress of lead and cadmium. Ecotoxicology and Environmental Safety, 208,

111582.

https://doi.org/10.1016/j.ecoenv.2020.1 11582

Sivakumar, S., Prabha, D., Velmurugan, P., Hong, S. C., Yi, P. I., Jang, S. H., \& Suh, J. M. (2020). Environmental Chemistry and Ecotoxicology Phytoremediation of $\mathrm{Cu}$ and Cd-contaminated roadside soils by using stem cuttings of Portulaca oleracea L. 2, 201-204. https://doi.org/10.1016/j.enceco.2020.1 0.004

Tanee, F.B.G and Amadi, N. (2016). Screening of Polyalthia longifolia and Aloe vera for their phytoextractability of heavy metals in tropical soil of the Niger Delta.Journal of Applied Science and Environmental Manage.20, 1: 141 - 147 (2016).

Usman, K., Al-ghouti, M. A., \& Abu-dieyeh, M. H. (2019). The assessment of cadmium , chromium , copper, and nickel tolerance and bioaccumulation by shrub plant Tetraena qataranse. Scientific Reports, October 2018, 1-11. https://doi.org/10.1038/s41598-01942029-9

Wang, Y., Liu, Q., Li, M., Yuan, X., Uchimiya, M., Wang, S., Zhang, Z., Ji, T., Wang, Y., \& Zhao, Y. (2021). Ecotoxicology and Environmental Safety Rhizospheric pore- water content predicts the biocharattenuated accumulation, translocation , and toxicity of cadmium to lettuce. Ecotoxicology and Environmental Safety, 208, 111675. https://doi.org/10.1016/j.ecoenv.2020.1 11675

Waziri, M., Abdullahi, U., Audu, A. A., \& Kalimullah. (2016). Phytoremediation Potentials of Selected Plants in Industrially Contaminated Soils. International Journal of Environmental Science and Development, 710$), 757-$ 762.

https://doi.org/10.18178/ijesd.2016.7.1 0.875

Wu, J., Lu, J., Li, L., Min, X., \& Luo, Y. (2018). Chemosphere Pollution, ecologicalhealth risks, and sources of heavy metals in soil of the northeastern Qinghai-Tibet Plateau. Chemosphere, 201, 234-242. https://doi.org/10.1016/j.chemosphere. 2018.02.122

Wu, Q., Wang, S., Thangavel, P., Li, Q., Zheng, H., Bai, J., \& Qiu, R. (2011). Phytostabilization potential of Jatropha curcas $\mathrm{I}$. in polymetallic acid mine tailings. International Journal of Phytoremediation, 13(8), 788-804. https://doi.org/10.1080/15226514.2010. 525562

Zulfiqar, U., Farooq, M., Hussain, S., Maqsood, M., Hussain, M., Ishfaq, M., Ahmad, M., \& Anjum, M. Z. (2019). Lead toxicity in plants: Impacts and remediation. Journal of Environmental Management, 250(September).

https://doi.org/10.1016/j.jenvman.2019. 109557

Álvarez-mateos, P., \& García-martín, J. F. (2019). Phytoremediation of highly contaminated mining soils by Jatropha curcas L . and production of catalytic carbons from the generated biomass. Journal of Environmental Management, 231(April 2018), 886-895. https://doi.org/10.1016/j.jenvman.2018. 10.052

Amir, W., Farid, M., Farid, S., Zubair, M., Alharby, H. F., Bamagoos, A. A., Rizwan, M., Raza, N., Rehman, K., \& Ali, S. (2020). Chemosphere Accumulation potential and tolerance response of Typha latifolia L . under citric acid assisted phytoextraction of lead and mercury. 257. https://doi.org/10.1016/j.chemosphere. 2020.127247 
BAJOPAS Volume 14 Number 1, June, 2021

Antoniadis, V., Shaheen, S. M., Stärk, H. J., Wennrich, R., Levizou, E., Merbach, I., \& Rinklebe, J. (2021). Phytoremediation potential of twelve wild plant species for toxic elements in a contaminated soil. Environment International, 146(October 2020).

https://doi.org/10.1016/j.envint.2020.10 6233

Bilal, H., Shahid Ali, S., \& - Min Kim, K. (2014). Potential of Eucalyptus in the Remediation of Environmental Problems: A review. International Journal of Innovation and Scientific Research ISSN, 4(2), 2351-8014. http://www.ijisr.issrjournals.org/

DalCorso, G., Fasani, E., Manara, A., Visioli, G., \& Furini, A. (2019). Heavy metal pollutions: State of the art and innovation in phytoremediation. International Journal of Molecular Sciences, 20(14). https://doi.org/10.3390/ijms20143412

Daryabeigi, A., Mikaeili, A., \& Vaezi, A. (2020). Environmental Technology \& Innovation Incorporation of biochar and nanomaterials to assist remediation of heavy metals in soil using plant species. Environmental Technology \& Innovation, 20,

101134. https://doi.org/10.1016/j.eti.2020.10113 4

Dobrikova, A. G., Apostolova, E. L., Han, A., Yotsova, E., Borisova, P., Sperdouli, I., Adamakis, I. S., \& Moustakas, M. (2021). Ecotoxicology and Environmental Safety Cadmium toxicity in Salvia sclarea L .: An integrative response of element uptake, oxidative stress markers, leaf structure and photosynthesis. 209. https://doi.org/10.1016/j.ecoenv.2020.1 11851

Godwin, E., \& Oluwagbemiga, D. (2020). Search for autochthonous plants as accumulators and translocators in a toxic metal-polluted coal mine soil in. Scientific African, 10, e00630. https://doi.org/10.1016/j.sciaf.2020.e00 630

Harcourt, P. (2016). JOURNAL OF APPLIED $S$ CIENCE AND E NVIRONMENTAL Screening of Polyalthia longifolia and Aloe vera for their phytoextractability of heavy metals in tropical soil of the Niger Delta.

Heidari, J., Amooaghaie, R., \& Kiani, S. (2020). Impact of chitosan on nickel bioavailability in soil, the accumulation and tolerance of nickel in Calendula tripterocarpa. International Journal of Phytoremediation, $\quad O(0), \quad 1-10$. https://doi.org/10.1080/15226514.2020. 1748564

Ibrahim, N., \& El, G. (2020). Heliyon Phytoremediation uptake model of heavy metals $(\mathrm{Pb}, \mathrm{Cd}$ and $\mathrm{Zn})$ in soil using Nerium oleander. Heliyon, 6(March), e04445. https://doi.org/10.1016/j.heliyon.2020.e 04445

Ji, C., Li, J., Jiang, C., Zhang, L., Shi, L., Xu, F., \& Cai, H. (2021). Zinc and nitrogen synergistic act on root-to-shoot translocation and preferential distribution in rice. Journal of Advanced Research, $X X X X$. https://doi.org/10.1016/j.jare.2021.04.0 05

Li, Xingyuan, Geng, T., Shen, W., Zhang, J., \& Zhou, Y. (2021). Ecotoxicology and Environmental Safety Quantifying the influencing factors and multi-factor interactions affecting cadmium accumulation in limestone-derived agricultural soil using random forest ( RF ) approach. Ecotoxicology and Environmental Safety, 209, 111773. https://doi.org/10.1016/j.ecoenv.2020.1 11773

Li, Xiong, \& Yang, Y. (2020). Plant Diversity Preliminary study on $\mathrm{Cd}$ accumulation characteristics in Sansevieria trifasciata Prain. Plant Diversity, 42(5), 351-355. https://doi.org/10.1016/j.pld.2020.05.00 1

Madanan, M. T., Shah, I. K., Varghese, G. K., \& Kaushal, R. K. (2021). Application of Aztec Marigold (Tagetes erecta L.) for phytoremediation of heavy metal polluted lateritic soil. Environmental Chemistry and Ecotoxicology, 3, 17-22. https://doi.org/10.1016/j.enceco.2020.1 0.007

Manikandan, M., Kannan, V., Mahalingam, K., Vimala, A., \& Chun, S. (2016). Phytoremediation potential of chromium-containing tannery effluentcontaminated soil by native Indian timber-yielding tree species. Preparative Biochemistry and Biotechnology, 46(1), 100-108.

https://doi.org/10.1080/10826068.2015. 1045607

Midhat, L., Ouazzani, N., Esshaimi, M., Ouhammou, A., \& Mandi, L. (2017). Assessment of heavy metals accumulation by spontaneous 
BAJOPAS Volume 14 Number 1, June, 2021 vegetation: Screening for new accumulator plant species grown in Kettara mine-Marrakech, Southern Morocco. International Journal of Phytoremediation, 19(2), 191-198. https://doi.org/10.1080/15226514.2016. 1207604

Mohammed, M. I., \& Inuwa, Y. (2018). Assessment of metals pollution in some herbs from Kano metropolis. Bayero Journal of Pure and Applied Sciences, 10(1), 356. https://doi.org/10.4314/bajopas.v10i1.7 $1 \mathrm{~s}$.

Navarro-ferna, C. M., Alegre, M., Robinson, B., \& Domı, T. (2017). Potential of Eucalyptus camaldulensis for phytostabilization and biomonitoring of trace- element contaminated soils. 1-22.

Pires-Lira, M. F., de Castro, E. M., Lira, J. M. S., de Oliveira, C., Pereira, F. J., \& Pereira, M. P. (2020). Potential of Panicum aquanticum Poir. (Poaceae) for the phytoremediation of aquatic environments contaminated by lead. Ecotoxicology and Environmental Safety, 193(October 2019), 110336. https://doi.org/10.1016/j.ecoenv.2020.1 10336

Sharma, P., Tripathi, S., \& Chandra, R. (2020). Heliyon Phytoremediation potential of heavy metal accumulator plants for waste management in the pulp and paper industry. Heliyon, 6(July), e04559. https://doi.org/10.1016/j.heliyon.2020.e 04559

Sharma, P., Tripathi, S., \& Chandra, R. (2021). Highly efficient phytoremediation potential of metal and metalloids from the pulp paper industry waste employing Eclipta alba (L) and Alternanthera philoxeroide (L): Biosorption and pollution reduction. Bioresource Technology, 319(August 2020), 124147. https://doi.org/10.1016/j.biortech.2020. 124147

Si, L., Zhang, J., Hussain, A., Qiao, Y., Zhou, J., \& Wang, X. (2021). Accumulation and translocation of food chain in soilmulberry (Morus alba L.)-silkworm (Bombyx mori) under single and combined stress of lead and cadmium. Ecotoxicology and Environmental Safety, 208, 111582. https://doi.org/10.1016/j.ecoenv.2020.1 11582

Steliga, T., \& Kluk, D. (2020). Application of Festuca arundinacea in phytoremediation of soils contaminated with $\mathrm{Pb}, \mathrm{Ni}, \mathrm{Cd}$ and petroleum hydrocarbons. Ecotoxicology and Environmental Safety, 194(October 2019), 110409. https://doi.org/10.1016/j.ecoenv.2020.1 10409

Tanee, F.B.G and Amadi, N. (2016). Screening of Polyalthia longifolia and Aloe vera for their phytoextractability of heavy metals in tropical soil of the Niger Delta.Journal of Applied Science and Environmental Manage.20, 1: 141 - 147 (2016).

Tang, L., Hamid, Y., Zehra, A., Sahito, Z. A., He, Z., Beri, W. T., Khan, M. B., \& Yang, X. (2020). Fava bean intercropping with Sedum alfredii inoculated with endophytes enhances phytoremediation of cadmium and lead co-contaminated field. Environmental Pollution, 265. https://doi.org/10.1016/j.envpol.2020.1 14861

Tauqeer, H. M., ur-Rahman, M., Hussain, S., Abbas, F., \& Iqbal, M. (2019). The potential of an energy crop "Conocarpus erectus" for lead phytoextraction and phytostabilization of chromium, nickel, and cadmium: An excellent option for the management of multi-metal contaminated soils. Ecotoxicology and Environmental Safety, 173(January), 273-284.

https://doi.org/10.1016/j.ecoenv.2019.0 1.119

Usman, K., Al-ghouti, M. A., \& Abu-dieyeh, M. H. (2019). The assessment of cadmium , chromium , copper, and nickel tolerance and bioaccumulation by shrub plant Tetraena qataranse. Scientific Reports, October 2018, 1-11. https://doi.org/10.1038/s41598-01942029-9

Wang, D., Li, G., Qin, S., Tao, W., Gong, S., \& Wang, J. (2021). Remediation of $\mathrm{Cr}(\mathrm{VI})$ contaminated soil using combined chemical leaching and reduction techniques based on hexavalent chromium speciation. Ecotoxicology and Environmental Safety, 208, 111734. https://doi.org/10.1016/j.ecoenv.2020.1 11734

Wang, J., Zhao, J., Feng, S., Zhang, J., Gong, S., Qiao, K., \& Zhou, A. (2020). Comparison of cadmium uptake and transcriptional responses in roots reveal key transcripts from high and low-cadmium tolerance ryegrass cultivars. Ecotoxicology and Environmental Safety, 203(July), 110961.

https://doi.org/10.1016/j.ecoenv.2020.1 
BAJOPAS Volume 14 Number 1, June, 2021 10961

Yang, W., Zhao, F., Wang, Y., Ding, Z., Yang, X., \& Zhu, Z. (2020). Differences in uptake and accumulation of copper and zinc by Salix clones under flooded versus nonflooded conditions. Chemosphere, 241, 125059.

https://doi.org/10.1016/j.chemosphere. 2019.125059

Zeng, P., Guo, Z., Cao, X., Xiao, X., Liu, Y., \& Shi, L. (2018). Phytostabilization potential of ornamental plants grown in soil contaminated with cadmium. International Journal of Phytoremediation, 20(4), 311-320. https://doi.org/10.1080/15226514.2017. 1381939

Zakari, A and Audu, A.A. (2021). Bioaccumulation and Translocation of Potentially Toxic Elements (PTEs) by Khaya Senegalensis at Challawa Industrial Estate, Kano, Nigeria, J. Mater. Environ. Sci., 12(5) 684-692. 